National and Global Petroleum Assessment

\title{
Assessment of Continuous Oil and Gas Resources in Jurassic Posidonia Shales of Greece and Albania, 2019
}

Using a geology-based assessment methodology, the U.S. Geological Survey estimated undiscovered, technically recoverable mean resources of 118 million barrels of continuous oil and 170 billion cubic feet of continuous gas in the Jurassic Posidonia Shale Total Petroleum System of western Greece and southern Albania.

\section{Introduction}

The U.S. Geological Survey (USGS) quantitatively assessed the potential for undiscovered, technically recoverable continuous oil and gas resources in the Jurassic Posidonia Shale Total Petroleum System (TPS) of western Greece and southern Albania (fig. 1). From the Late Triassic to Early Jurassic, this area of western Greece and southern Albania was part of a regionally extensive carbonate platform that developed on and around the Apulian Plate (Karakitsios, 1995; 2013). Deposited along the passive margin during this time were as much as 1,000 meters of platform carbonates of the Pantokrator Limestone. Jurassic extension and rifting associated with the opening of the neo-Tethys Ocean led to the formation of numerous grabens and half-grabens along the margin of the Apulian Plate (Karakitsios, 1995; Karakitsios and Rigakis, 2007). The bottom waters of the deeper grabens and half-grabens were anoxic, resulting in the deposition and preservation of organic-rich petroleum source rocks of the Jurassic Posidonia Shale. These extensional structures persisted through the Jurassic and eventually were buried by the regionally extensive, postrift Cretaceous Vigla Limestone. From the Cretaceous through the Paleogene, the Apulian Plate was relatively undeformed and buried by perhaps hundreds of meters of carbonate deposits. Beginning in the Eocene and ending in the Miocene, the Apulian Plate collided with the Eurasian Plate, forming the Dinaride and Hellenide fold and thrust belts, resulting in compressional deformation of Mesozoic rocks. Associated with the collision of Apulia was the progradation of orogenic clastic wedges up to several kilometers thick (Gonzalez-Bonorino, 1996; Karakitsios, 2013). Neogene burial by these orogenic clastics resulted in the thermal maturation into the oil- and gas-generation windows of the Jurassic Posidonia source rocks (Rigakis and Karakitsios, 1998; Karakitsios and Rigakis, 2007).

\section{Total Petroleum System and Assessment Units}

The USGS defined the Jurassic Posidonia Shale TPS and two continuous assessment units (AUs) within the TPS (fig. 1). The Jurassic Posidonia Shale Oil AU and the Jurassic Posidonia Shale Gas AU were defined based on thickness of organic-rich shale, total organic carbon content, and levels of thermal maturation for oil and gas.

Jurassic Posidonia organic-rich shales form some of the most prolific petroleum source rocks in Europe and have been studied extensively (van Bergen and others, 2013; Song and others, 2017; Stock and Littke, 2018). Jurassic Posidonia Shales in Greece and Albania contain Type II and Type I organic matter, have as much as 20 weight percent total organic carbon, have hydrogen indices as much as 565 milligrams of hydrocarbon per gram of total organic carbon, are up to 80 meters thick, and are interpreted to be thermally mature both for oil and gas (Rigakis and Karakitsios, 1998; Zelilidis and others, 2003; Karakitsios and Rigakis, 2007; Barbullushi, 2013; Karakitsios, 2013; Spathopoulos and Sephton, 2013; Zelilidis and others, 2013).

The Jurassic Posidonia Shale source rocks have been studied in detail with respect to geochemical data such as organic carbon content, hydrogen index, and kerogen composition. However, the geologic uncertainty in this assessment revolves around the extent and level of thermal maturation of organic matter in the shales and the extent of retention of oil and gas within the shales following deformation, expulsion, and mainly Neogene migration.

The geologic model underlying the assessment of the Jurassic Posidonia Shale Oil AU and Jurassic Posidonia Shale Gas AU is for oil and gas to have been generated within these organic-rich shales during burial by Eocene-to-Neogene orogenic clastic wedges. Thermal maturation coincided with Neogene compression and deformation, and the model requires that some portion of the oil and gas was retained within the shales following expulsion and migration.

The assessment input data are summarized in table 1.

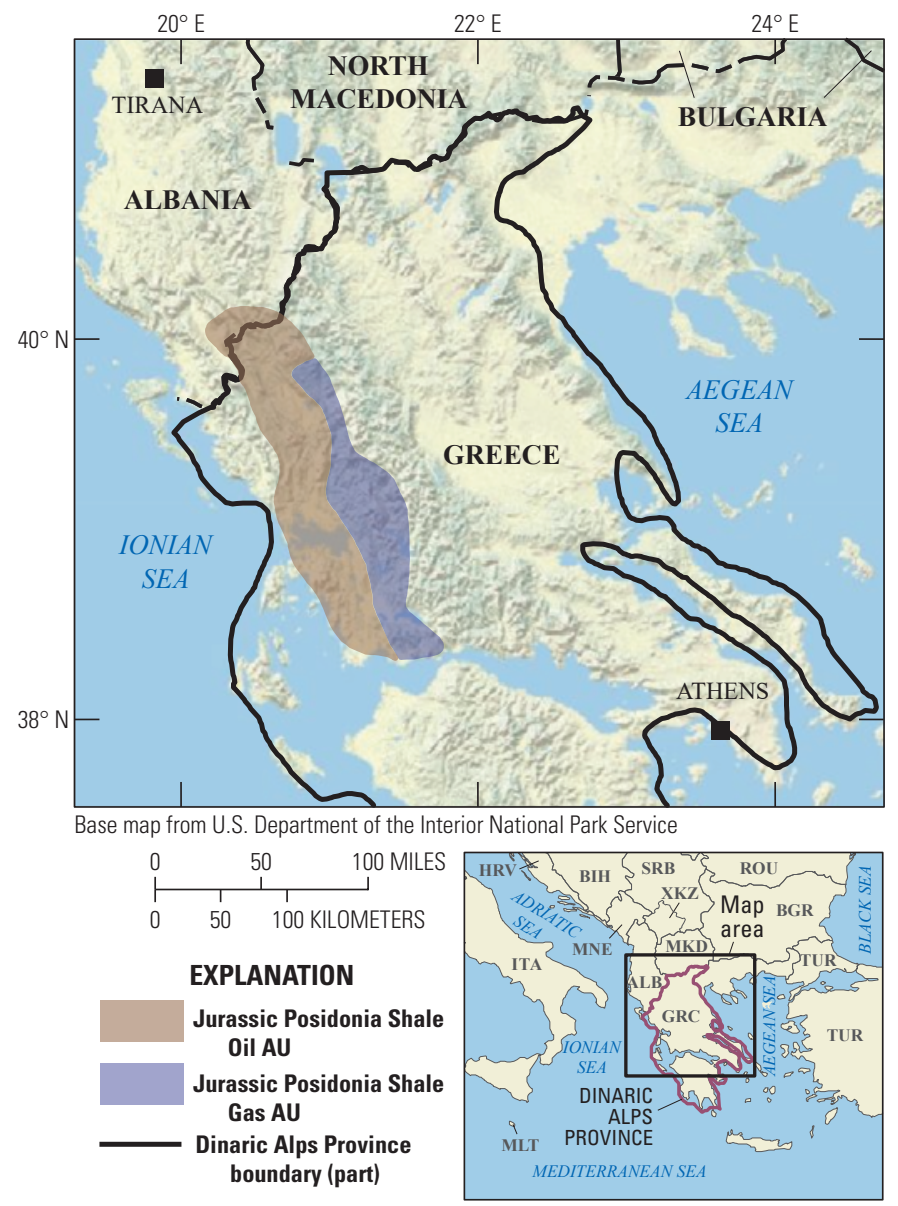

Figure 1. Map showing the location of two continuous assessment units in the Jurassic Posidonia Shale Total Petroleum System of western Greece and southern Albania and the Dinaric Alps Province boundary. 
Table 1. Key input data for two continuous assessment units in the Jurassic Posidonia Shale Total Petroleum System of western Greece and southern Albania.

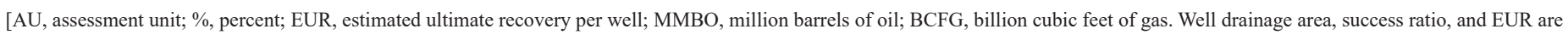
defined partly using U.S. shale-oil and shale-gas analogs. The average EUR input is the minimum, median, maximum, and calculated mean. Shading indicates not applicable]

\begin{tabular}{|c|c|c|c|c|c|c|c|c|}
\hline \multirow{2}{*}{$\begin{array}{l}\text { Assessment input data- } \\
\text { Continuous AUs }\end{array}$} & \multicolumn{4}{|c|}{ Jurassic Posidonia Shale Oil AU } & \multicolumn{4}{|c|}{ Jurassic Posidonia Shale Gas AU } \\
\hline & Minimum & Mode & Maximum & $\begin{array}{l}\text { Calculated } \\
\text { mean }\end{array}$ & Minimum & Mode & Maximum & $\begin{array}{l}\text { Calculated } \\
\text { mean }\end{array}$ \\
\hline Potential production area of AU (acres) & 1,000 & 849,000 & $1,698,000$ & 849,333 & 1,000 & 491,000 & 982,000 & 491,333 \\
\hline Average drainage area of wells (acres) & 60 & 100 & 140 & 100 & 80 & 120 & 160 & 120 \\
\hline Area untested in $\mathrm{AU}(\%)$ & 100 & 100 & 100 & 100 & 100 & 100 & 100 & 100 \\
\hline Success ratio $(\%)$ & 10 & 40 & 80 & 43.3 & 10 & 40 & 80 & 43.3 \\
\hline Average EUR (MMBO, oil; BCFG, gas) & 0.01 & 0.04 & 0.15 & 0.046 & 0.04 & 0.07 & 0.1 & 0.071 \\
\hline AU probability & 0.7 & & & & 0.6 & & & \\
\hline
\end{tabular}

\section{Undiscovered Resources Summary}

The USGS quantitatively assessed undiscovered, technically recoverable continuous oil and gas resources within the Jurassic Posidonia Shale TPS of western Greece and southern Albania (table 2). The estimated mean totals for continuous resources are 118 million barrels of oil (MMBO) with an F95-F5 range from 0 to $368 \mathrm{MMBO}, 170$ billion cubic feet of gas (BCFG) with a F95-F5 range from 0 to 539 BCFG, and 1 million barrels of natural gas liquids (MMBNGL) with an F95-F5 range from 0 to 5 MMBNGL. The zeros at the F95 fractiles reflect uncertainty in the geologic model, particularly with respect to the retention of oil or gas within Posidonia Shales.

Table 2. Results for two continuous assessment units in the Jurassic Posidonia Shale Total Petroleum System of western Greece and southern Albania.

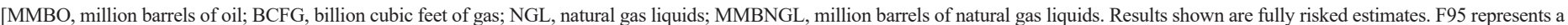

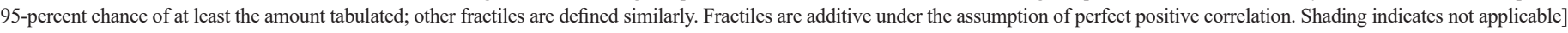

\begin{tabular}{|c|c|c|c|c|c|c|c|c|c|c|c|c|c|c|}
\hline \multirow{3}{*}{$\begin{array}{l}\text { Total petroleum system and } \\
\text { assessment units (AUs) }\end{array}$} & \multirow{3}{*}{$\begin{array}{l}\text { AU } \\
\text { prob- } \\
\text { ability }\end{array}$} & \multirow{3}{*}{$\begin{array}{c}\text { Accu- } \\
\text { mulation } \\
\text { type }\end{array}$} & \multicolumn{12}{|c|}{ Total undiscovered resources } \\
\hline & & & \multicolumn{4}{|c|}{ Oil (MMBO) } & \multicolumn{4}{|c|}{ Gas (BCFG) } & \multicolumn{4}{|c|}{ NGL (MMBNGL) } \\
\hline & & & F95 & $\mathbf{F 5 0}$ & F5 & Mean & F95 & F50 & F5 & Mean & F95 & $\mathbf{F 5 0}$ & F5 & Mean \\
\hline \multicolumn{15}{|c|}{ Jurassic Posidonia Shale Total Petroleum System } \\
\hline Jurassic Posidonia Shale Oil AU & 0.7 & Oil & 0 & 90 & 368 & 118 & 0 & 68 & 302 & 94 & 0 & 1 & 4 & 1 \\
\hline Jurassic Posidonia Shale Gas AU & 0.6 & Gas & & & & & 0 & 58 & 237 & 76 & 0 & 0 & 1 & 0 \\
\hline Total undiscovered continuous resources & & & 0 & 90 & 368 & 118 & 0 & 126 & 539 & 170 & 0 & 1 & 5 & 1 \\
\hline
\end{tabular}

\section{References Cited}

Barbullushi, R., 2013, Basin evolution and hydrocarbon plays in Albania: American Association of Petroleum Geologists, Search and Discovery Article No. 10504, 19 p., accessed August 7, 2019, at http://www.searchanddiscovery.com/pdfz/ documents/2013/10504barbullushi/ndx_barbullushi.pdf.html.

Gonzalez-Bonorino, G., 1996, Foreland sedimentation and plate interaction during closure of the Tethys Ocean (Tertiary; Hellenides; western continental Greece): Journal of Sedimentary Research, v. 66, no. 6, p. 1148-1155.

Karakitsios, V., 1995, The influence of preexisting structure and halokinesis on organic matter preservation and thrust system evolution in the Ionian Basin, northwest Greece: The American Association of Petroleum Geologists Bulletin, v. 79, no. 7, p. 960-980.

Karakitsios, V., 2013, Western Greece and Ionian Sea petroleum systems: The American Association of Petroleum Geologists Bulletin, v. 97, no. 9, p. 1567-1595.

Karakitsios, V., and Rigakis, N., 2007, Evolution and petroleum potential of western Greece: Journal of Petroleum Geology, v. 30, no. 3, p. 197-218.

Rigakis, N., and Karakitsios, V., 1998, The source rock horizons of the Ionian Basin (NW Greece): Marine and Petroleum Geology, v. 15, no. 7, p. 593-617.

Song, J., Littke, R., and Weniger, P., 2017, Organic geochemistry of the Lower Toarcian Posidonia Shale in NW Europe: Organic Geochemistry, v. 106, p. $76-92$.

Spathopoulos, F., and Sephton, M.A., 2013, Unconventional petroleum plays in the Mediterranean Basins: American Association of Petroleum Geologists,
Search and Discovery Article No. 10495, 51 p., accessed August 9, 2019, at http://www.searchanddiscovery.com/pdfz/documents/2013/ 10495spathopoulos/ndx_spathopoulos.pdf.html.

Stock, A.T., and Littke, R., 2018, The Posidonia Shale of northern GermanyUnconventional oil and gas potential from high-resolution 3D numerical modelling of the cross-junction between the eastern Lower Saxony Basin, Pompeckj Block and Gifhorn Trough, in Kilhams, B., Kukla, P.A., Mazur, S., McKie, T., Mijnlieff, H.F., van Ojik, K., and Geluk, M.C., eds., Mesozoic resource potential in the southern Permian Basin: The Geological Society of London, Special Publication 469, 23 p.

van Bergen, F., Zijp, M., Nelskamp, S., and Kombrink, H., 2013, Shale gas evaluation of the Early Jurassic Posidonia Shale Formation and the Carboniferous Epen Formation in the Netherlands, chap. 1 of Chatellier, J. and Jarvie, D., eds., Critical assessment of shale resource plays: American Association of Petroleum Geologists, Memoir No. 103, p. 1-24.

Zelilidis, A., Piper, D.J.W., Vakalas, I., Avramidis, P., and Getsos, K., 2003, Oil and gas plays in Albania-Do equivalent plays exist in Greece?: Journal of Petroleum Geology, v. 26, no. 1, p. 29-48.

Zelilidis, A., Konstantopoulos, P., and Maravelis, A., 2013, Hydrocarbon prospectivity in Apulian Platform and Ionian Zone, in relation to strike-slip fault zones, foreland and back-thrust basins of Ionian thrust in Greece: American Association of Petroleum Geologists, Search and Discovery Article No. 10496, 46 p., accessed August 7, 2019, at http://www.searchanddiscovery.com/pdfz/documents/2013/10496zelilidis/ ndx_zelilidis.pdf.html.

\section{For More Information}

Assessment results are also available at the USGS Energy Resources Program website at https://energy.usgs.gov.

\section{Greece and Albania Assessment Team}

Christopher J. Schenk, Tracey J. Mercier, Marilyn E. Tennyson, Thomas M. Finn, Cheryl A. Woodall, Michael E. Brownfield, Kristen R. Marra, Heidi M. Leathers-Miller, Phuong A. Le, and Ronald M. Drake II 